\title{
Ethnobotanical Knowledge of Pastoral Community for Treating Livestock Diseases in Shinle Zone, Somali Regional State, Eastern Ethiopia
}

\section{Melese Mengistu ${ }^{1 *}$, Ewonetu Kebede ${ }^{2}$ and Biresaw Serda ${ }^{3}$}

${ }^{1}$ School of Plant Sciences, Haramaya University, PO Box 138, Dire Dawa, Ethiopia

${ }^{2}$ School of Animal and Range Sciences, Haramaya University, PO Box 138, Dire Dawa, Ethiopia

${ }^{3}$ College of Veterinary Medicine, Haramaya University, PO Box 138, Dire Dawa, Ethiopia

\begin{abstract}
Background: Modern livestock health care is still at its lowest stage in Ethiopia and most modern veterinary services like drugs and veterinary professionals are not accessible and affordable to the majority of pastoral farmers. As a result, they are heavily relying on their traditional knowledge and practices on locally available materials mainly plants in the management of animal diseases. However, this traditional knowledge has not yet been well documented and analyzed. Therefore, this study was conducted to identify medicinal plants and examine factors that threaten ethno-veterinary.

Methods: This study was conducted in Ethiopian Somaliland regional state, Shinle zone. Survey was conducted to gather information from 180 households on indigenous knowledge using a semi-structured questionnaire and filed guided observations. The data was collected and analyzed using SPSS. The variability of documented knowledge and the homogeneity of the information given by the respondents were estimated by informant consensus factor.

Results: Thirty-one plant species belonging to eighteen families used against fourteen types of livestock health problems. Majority of plant identified fall under Fabaceae (22.5\%) and Euphorbiaceae (16.1\%) family that are largely shrubs. The most commonly used plant parts were roots $(35.5 \%)$ followed by leaves $(25.8 \%)$. Remedy preparation was mainly through chop and soak in concoction of water and salt. Oral, topical and nasal route were the common mode of administration with no standardized dosing and treatment duration. The principal threats of medicinal plants were invasive plants, drought, over grazing, agricultural activity and firewood collection. Indigenous knowledge on ethno-veterinary medicinal plants was accepted orally from healer's forefathers and transmitted similarly.

Conclusion: Awareness should be raised and ethno-veterinary medicine should be integrated in to livestock extension delivery systems for the need to exploit the possibility of discovering more medicinally viable plants. Further studies needed under controlled conditions on the efficacy of such plants.
\end{abstract}

Keywords: Ethno-veterinary; Livestock; Medicinal plants; Pastoralists; Plant species

\section{Introduction}

Medicinal plants traditionally used in the treatment of animal diseases play a crucial role in local health modalities [1]. The use of ethno-veterinary medicine (EVM) may present a cheaper and sustainable alternative to synthetic medicines in the present and future [2]. These herbal preparations, drawing upon centuries of traditional belief and use, are in practice over time by pastoralists and farmers for the treatment of different diseases of livestock [3]. About $65-80 \%$ of the world's population in developing countries depends on plants for their primary healthcare due to poverty and lack of access to modern medicine [4]. Likewise $80 \%$ of the total population of Ethiopia is depending on traditional medicine to treat different types of human illness and animals [5]. According to the United Nations Food and Agricultural Organization, lack of drugs to treat diseases and infections results in losses of $30-35 \%$ in the breeding sector of many developing countries, where poor animal health remains the major constraint to increased production [6].

Modern livestock health care in pastoral community of Ethiopia is still at its lowest stage due to limited veterinary services and supply of drugs. Besides, most modern drugs are expensive and, as a result, not affordable by the majority of Ethiopian farmers and pastoralists. As a result, pastoral and agro-pastoral communities heavily rely on their traditional knowledge and practices on locally available materials mainly plants in the management of animal diseases. However; this traditional knowledge has not yet been well documented and so far very little of the ethno-veterinary knowledge in Ethiopia is properly documented and analyzed [7]. Moreover, the knowledge of ethno-veterinary transmitted from generation to generation mainly orally; consequently, it remains fragile and threatened, and presents an urgent need for being record and document for prospect utilization. Therefore, this study was conducted to identify medicinal plants and examine factors that threaten ethnoveterinary in the study area.

\section{Materials and Methods}

\section{Description of the study area}

This study was conducted in Ethiopian Somaliland regional state, Shinle zone. It is located at about $517 \mathrm{Km}$ east of Addis Ababa and $15 \mathrm{Km}$

*Corresponding author: Melese Mengistu, School of Plant Sciences, Haramaya University, PO Box 138, Dire Dawa, Ethiopia, Tel: 251255530051; E-mail melese43@yahoo.com (or) ewonetu2011@gmail.com

Received August 31, 2017; Accepted September 25, 2017; Published September 26, 2017

Citation: Mengistu M, Kebede E, Serda B (2017) Ethnobotanical Knowledge of Pastoral Community for Treating Livestock Diseases in Shinle Zone, Somali Regional State, Eastern Ethiopia. J Vet Sci Technol 8: 474. doi: 10.4172/2157 7579.1000474

Copyright: () 2017 Mengistu M, et al. This is an open-access article distributed under the terms of the Creative Commons Attribution License, which permits unrestricted use, distribution, and reproduction in any medium, provided the original author and source are credited. 
from Dire-Dawa. The area's altitude ranges between 950-1300 meters above sea level. Annual average rainfall and the average temperature of the area are $500-700 \mathrm{~mm}$ and $27.5^{\circ} \mathrm{C}$, respectively [8]. About 85 $95 \%$ of Shinile district population depends on livestock and livestock products for their livelihood and the rest, $5-15 \%$ are engaged in the crop-livestock production and cross border trade. The pastoralists keep the full range of livestock in total livestock unit (TLU): 90000 sheep, 55000 cattle, 100000 goats and 60000 camels [9].

\section{Study subjects and sampling method}

Shinile zone is located in Somali Regional State, which consists six districts such as Afdem, Ayesha, Dembel, Erer, Mieso and Shinile. Among the pastoral area of Shinile zone, Erer, Shinile and Dembel districts were purposively selected on the bases of their livestock production potential and ethno-veterinary knowledge. One hundred eighty households (Sixty from each district) which were traditional healers who practiced providing services related to veterinary medicinal plants for at least a year purposively selected and interviewed [10].

\section{Data collection}

Survey conducted to gather information from pastoral communities on traditional usage of plants in livestock health care system using a semi-structured interview, observations and field guided walks with traditional healers to share their indigenous knowledge. Data collected from respondents include local name of medicinal plant, diseases treated, animal species treated, distance from the house to place where plant species gathered, seasonality of plant species, degree of management (wild/cultivated), abundance, parts used, condition of plant part used (fresh/dried), other ingredients or additives, methods of medicine preparation, preservation, dosage prescriptions, routes of remedy administration, noticeable adverse effects of remedies, use of antidote for adverse effects, source and method of indigenous knowledge transfer, existing threats and traditional conservation practices, marketability of medicinal plant species and income earned per animal treated for any disease.

\section{Plant identification}

Specimens of plants with leaves and roots, and including floral parts, as it was appropriate for taxonomic identification were collected. The specimens coded by their vernacular names and transported by plastic bag to Haramaya University Botany laboratory where it identified and authenticated.

\section{Statistical analysis}

The data collected was analyzed using statistical package for social sciences (SPSS) version 16. The variability of documented knowledge of ethno-veterinary medicine and the homogeneity of the information given by the respondents were estimated by informant consensus factor (ICF) $[11,12]$.

$$
I C F=\frac{n u r-n t}{n u r-1}
$$

Where: nur=Number of usage-reported by informant, $n t=$ Number of plant species used.

\section{Results and Discussion}

\section{Respondents' demographic characteristics}

The majority of respondents were males (Table 1) and this marked difference reflects the limited involvement of women in livestock production and herd health in pastoral areas. Similarly, Giday et al. observed that men had more knowledge of plant usage because they are naturally selected during childhood to be trainees of ethno-veterinary practices [13]. In addition, in some regions, labor division makes women responsible for housekeeping only, while men take care of the animals [14]. The age characteristics indicated that most of respondents were elder (Table 1) and the concern expressed by some elder informants that young people were not interested in ethno-veterinary medicine (EVM). The young generation had little knowledge about the traditional medicines while the elder people know much more about the traditional knowledge to treat livestock ailments. This finding is in line with the study of Yirga and Zerabruk who reported that majority of the respondents involved in traditional livestock treatment were old age people [15].

\section{Medicinal plants and its application}

Thirty-one plant species were used against 14 types of livestock diseases that have uncomplicated symptoms (Table 2). This study suggested that the highest number of plant species found in Fabaceae family followed by Euphorbiaceae. In agreement to current finding, the dominant use of Cucurbitaceae, Euphorbiaceae, Fabaceae and Solanaceae families have been noticed by Ashagre et al. to be used for treatment of cattle diseases in other part of the country [16]. Such widespread use of these plants by different groups of societies in different countries could be to a certain extent attributed to their efficacy. In other words, the ethno medicinal reports of those species from wider geographical regions and different cultural groups could validate the medicinal properties of these species.

Diarrhea was the one against which a high number of medicinal plants species were prescribed (Table 3 ). These disease conditions reported in current study comparable to those reported by Gabriel A whose study indicated many similar diseases such as worms

\begin{tabular}{|c|c|c|c|c|c|c|c|c|}
\hline \multirow{2}{*}{ Variables } & \multicolumn{2}{|c|}{ Shinile } & \multicolumn{2}{|c|}{ Erer } & \multicolumn{2}{|c|}{ Dembel } & \multicolumn{2}{|c|}{ Total } \\
\hline & $\mathbf{N}$ & $\%$ & $\mathbf{N}$ & $\%$ & $\mathbf{N}$ & $\%$ & $\mathbf{N}$ & $\%$ \\
\hline \multicolumn{9}{|c|}{ Age } \\
\hline$<40$ & 13 & 7.2 & 11 & 6.1 & 15 & 8.3 & 39 & 21.7 \\
\hline $40-50$ & 29 & 16.1 & 27 & 15 & 25 & 13.9 & 81 & 45 \\
\hline$>55$ & 18 & 10 & 22 & 12.2 & 20 & 11.1 & 60 & 33.3 \\
\hline \multicolumn{9}{|c|}{ Gender } \\
\hline Male & 51 & 28.3 & 48 & 26.7 & 54 & 30 & 153 & 85 \\
\hline Female & 9 & 5 & 12 & 6.7 & 6 & 3.3 & 27 & 15 \\
\hline \multicolumn{9}{|c|}{ Educational status } \\
\hline Primary school & 19 & 10.5 & 22 & 12.2 & 16 & 8.9 & 57 & 31.7 \\
\hline Illiterate & 41 & 22.8 & 38 & 21.1 & 44 & 24.4 & 123 & 68.3 \\
\hline
\end{tabular}

Table 1: Demographic characteristics of respondents in the study Area $(\mathrm{N}=180)$. 
Citation: Mengistu M, Kebede E, Serda B (2017) Ethnobotanical Knowledge of Pastoral Community for Treating Livestock Diseases in Shinle Zone, Somali Regional State, Eastern Ethiopia. J Vet Sci Technol 8: 474. doi: 10.4172/2157-7579.1000474

Page 3 of 8

\begin{tabular}{|c|c|c|}
\hline Families & Number of species & $\%$ \\
\hline Berberidaceae & 1 & 3.2 \\
\hline Rubiaceae & 1 & 3.2 \\
\hline Meliaceae & 2 & 6.4 \\
\hline Fabaceae & 7 & 22.6 \\
\hline Euphorbiaceae & 5 & 16.1 \\
\hline Liliaceae & 1 & 3.2 \\
\hline Olearaceae & 1 & 3.2 \\
\hline Aloaceae & 2 & 6.4 \\
\hline Myrtaceae & 1 & 3.2 \\
\hline Polygonaceae & 1 & 3.2 \\
\hline Solanaceae & 2 & 9.7 \\
\hline Asteraceae & 1 & 3.2 \\
\hline Lythraceae & 1 & 3.2 \\
\hline Lamiaceae & 1 & 3.2 \\
\hline Balantaceae & 1 & 3.2 \\
\hline Cyperaceae & 1 & 3.2 \\
\hline Zingiberaceae & 1 & 3.2 \\
\hline Rutaceae & 1 & 3.2 \\
\hline
\end{tabular}

Table 2: Plant families identified in the study area.

\begin{tabular}{|c|c|c|c|c|c|c|}
\hline Types of diseases & Local name & Plant species (N) & $\%$ & Informant cited (N) & $\%$ & ICF \\
\hline CCPP/ Cough & Qufac iyo lab wareen & 3 & 9.7 & 29 & 24.2 & 0.93 \\
\hline Diarrhea & Shuban & 7 & 22.6 & 17 & 14.2 & 0.62 \\
\hline Wound healing & Boog & 3 & 9.6 & 27 & 45.0 & 0.93 \\
\hline Ectoparasites (ticks) & & 1 & 3.2 & 37 & 30.8 & 1.00 \\
\hline Bloating & & 2 & 6.4 & 22 & 18.3 & 0.95 \\
\hline Evil eye & Shaydaan & 1 & 3.2 & 9 & 7.5 & 1.00 \\
\hline Body swell & Jidh barar & 3 & 9.7 & 15 & 12.5 & 0.86 \\
\hline Kidney problems (like Bloody Urine) & Infekshinka kaadi mareenka & 2 & 6.4 & 19 & 15.8 & 0.94 \\
\hline Eye problems & Gaaska caloosha & 1 & 3.2 & 21 & 17.5 & 1.00 \\
\hline Hayna bite & & 1 & 3.2 & 15 & 12.5 & 1.00 \\
\hline $\begin{array}{c}\text { Skin diseases like lesions/ } \\
\text { dermatophilosis }\end{array}$ & Xanuunka maqaarka & 1 & 3.2 & 43 & 35.8 & 1.00 \\
\hline Snake bite & & 2 & 6.4 & 7 & 5.8 & 0.83 \\
\hline $\begin{array}{l}\text { Internal parasite/like } \\
\text { tape worm }\end{array}$ & & 2 & 6.4 & 39 & 32.5 & 0.97 \\
\hline Rabies (mad dog bite) & & 2 & 6.4 & 43 & 35.8 & 0.97 \\
\hline
\end{tabular}

Table 3: Livestock diseases treated by medicinal plants in the study area. N.B: CCPP = Contagious caprine pleuropneumonia.

(external parasites), diarrhea, eye infection, cough, bloat, wounds and ectoparasites [17]. Similarly, Nalule reported diseases or conditions like bloat, trypanosomiasis, skin diseases, CBPP, FMD [18]. Elsewhere, trypanosomiasis, diarrhea, bloat, helminthiasis, snake bites and wounds were the common diseases reported by Adeola et al. [19]. Among the factors which made the people of the study area to rely on indigenous knowledge to treat livestock disease is inaccessibility to veterinary clinics and veterinarian to community living in marginal areas and the conventional drugs are also unaffordable to the less economically endowed people. This finding also supported Abebe et al. [20] who reported that people recognizing the value of indigenous knowledge to solve their animal health problems in an accessible way and economic affordability. The inconsistency and sometimes-complete absence of conventional veterinary services by the government and private sector has led the pastoralists to stick and relay on the traditional treatment systems followed by their ancestors [21].

\section{Sources and growth habit of medicinal plants}

Analysis of the growth forms of ethno-veterinary medicinal plants in the study area revealed that shrubs constituted the largest number or proportion with 12 species whereas herbs and trees account 11 species and 8 species, respectively (Table 6). Dominance of shrubs was also reported by earlier ethno-botanical inventories [22-25]. In contrast, other investigators [7,26-29] reported dominance of herbaceous species for ethno-medicinal preparation in elsewhere. Also, Yibrah reported that trees and herbaceous medicinal plants were the widely used for the treatment of various ailments that constituting $51.72 \%$, and $24.14 \%$, respectively, followed by $13.79 \%$ shrub and $10.34 \%$ climbers [30]. However, the variation in dominance of growth forms of medicinal plants used among different traditional healers in the country attributed to the wide agro-ecological diversity and specific indigenous knowledge of different communities. All respondents of traditional healers in the study area were harvesting medicinal plants from the wild environment. Comparable trends in harvesting medicinal plants from the wild were also reported [23,27,31-33]. Sinha et al. also reported, as medicinal plants have been growing in natural habitats (wild) and exploited to cure ailments by collecting them from natural habitats [34]. Likewise, in other parts of the country, ethno veterinary medicinal plants mainly collected from the wild stands as reported by Yirga et al. [35]. The finding of current study also agrees 
with the finding of Habibul [36] in which wild plants mostly collected for livestock treatment. Similarly, Yibrah reported that most of the plant species collected from wild habitats $(72.41 \%)$, and few of them obtained from around home garden $(27.59 \%)$ and exploited to cure and control the livestock and human diseases [30]. This result indicates that medicinal plant species poorly preserved in the study area.

\section{Plant parts used and mode of remedy preparation}

The traditional healers were using different parts of medicinal plants identified in the study area (Figure 1). Roots of the plants were the parts most frequently used to treat livestock aliments, followed by leaves however mixed uses of plant parts were rare (Figure 1). The finding agrees with the result of Gabriel [17] who stated that root was identified as the most frequently used (70\%) plant part followed by whole plant (7.5\%), fruit (5\%), leaves and stem (5\%) for treatment of cattle diseases in Uganda. Many studies conducted elsewhere in Ethiopia showed the dominance of leaves in the preparation of remedies. This was because leaves contain many metabolites with characteristic anti-illness effects $[24,32,37,38]$. In contrast, Birhane et al. [39] indicated root as the most commonly harvested plant part in a study carried out in other Ethiopian regions. A study conducted in Oromia region of Ethiopia also witnessed the common usage of root [23]. Harvesting root of a plant poses more threat to survival of plant than collecting other parts such as fruits, seeds and leaves [40]. Such widespread harvesting of roots or leaves, which are important for plant survival, threatens the survival and continuity of valuable medicinal plants. A plant whose roots are most used is more susceptible to extinction than that whose leaves and fruits are used unless proper conservation and sustainable measures are considered [18].

Medicinal plant used in this study were in the form of fresh (67.7\%), dry $(22.6 \%)$ and both in the form of fresh and dry $(9.4 \%$ (Table 6). Most of traditional healers (97.8\%) reported that they collected and immediately use with no preservation but few $(2.2 \%)$ preserved the plant materials by various ways like pounding and saving the powder or hanging the dried plant part either in the roof of their home or under the leaves. Ref. [16] reported similar findings, as local community employed several methods of preparation of traditional medicines from plants, $91.5 \%$ of herbal preparations were from fresh plant parts followed by dried parts in agro-pastoralists. For immediate application of fresh plant, most healers (97.8\%) chop and soak in water with salt overnight then squeezed to separate liquid extract whereas few (2.2\%) practiced crushing and forming powder then diluted by water when need arise for plants used in dry form and it were made from preserved parts of plant. This finding is analogous to [41] who reported grinding or crushing and soaking or boiling as the most common

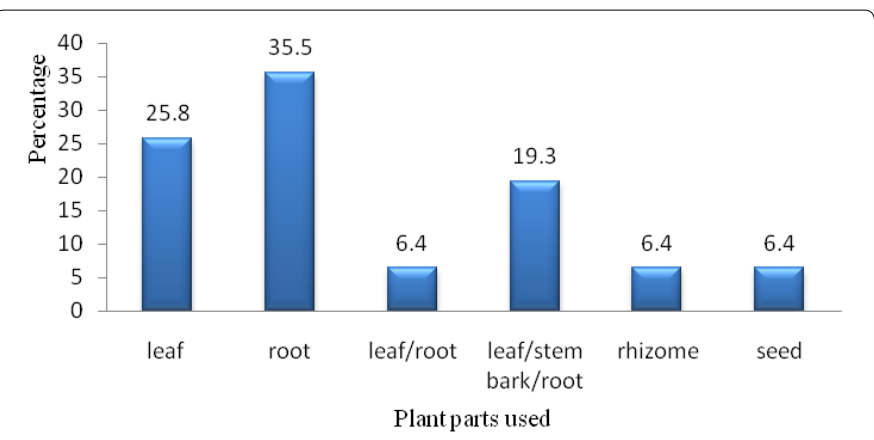

Figure 1: Parts of medicinal plants used as remedy for livestock treatment in the study areas. method of drugs extraction from plants. Preparations of remedies in study area involved single medicinal plant, which is in agreement with the findings of studies conducted elsewhere in Ethiopia $[28,42]$ while it is believed that the potency of plant remedies could be enhanced when they are used in concoction form [43].

\section{Route of remedy administration and dosage}

Analysis of mode of administration showed oral route (71\%) was the most common followed by topical (22.6\%) and nasal (6.4\%) route. Those findings were consistent with findings of Teshale who reported as most of medicinal plants used by pastoralists administered through oral route followed by dermal route [44]. In study conducted by Kebu et al. reported that greater than half of plant remedies studied administered orally [45]. A few studies, however, reported predominantly the dermal application of remedies and to lesser extent oral administration [35]. Similar to this study finding, Ashagre et al. reported oral route as the most commonly used route of administration of traditional remedies [16]. Similarly, Gabriel A reported three different routes of administration of which oral route $(68.5 \%)$ was the highest, followed by topical route $(22.2 \%)$ and eye drop (9.3\%) [17]. Majority of traditional healers $(94.85 \%)$ were not reported standardized dosing and treatment duration while few respondents were using different local measurement units to determine the dosage of plant medicine and treatment duration. Local units for instance, half cup, full cup, and liter employed depending on age and types of livestock species to be treated. The dose determination varied from healer to healer, disease to disease, even for the same type of ailment and the dose given depends on age, physical appearance and health conditions. This also observed in other ethno-veterinary surveys $[13,14,27]$. Majority healers $(87.6 \%)$ prescribed plant remedies for livestock treatments until cure whereas few healers (12.4\%) administered for a week. In this study, all respondents reported as the remedies have no adverse effects on animals. The variation in quantity, unit of measurement, and duration of treatment of prescribed plant preparations also noted in a study conducted elsewhere in the country [39]. Getahun reported that lack of precision and standardization of preparations are two of the drawbacks of traditional health care system [46].

\section{Preference ranking of medicinal plants}

The first two preferred medicinal plants used against diarrhea were Acalyph indica $\mathrm{L}$, and Olea europeae $\mathrm{L}$ according to preference ranking conducted using traditional healers (Table 4).

\section{Mode of ethno-veterinary knowledge transfer}

The mode of transfer of indigenous knowledge on ethno-veterinary medicinal plants in the study area was not codified in written form; all healers are accepted orally from their forefathers and transmitted similarly to their children, most often to the one who keep their secret. This was corresponding with studies in other parts of Ethiopia [13], Pakistan [13] and Brazil [47,48]. The apparent lack of transfer of ethnoveterinary knowledge from older to younger generations was a cause of concern in all studies $[49,50]$.

\section{Threats to medicinal plants}

The major factors affecting the wealth of medicinal plants in the study area indicated in Table 5. The principal threats of medicinal plants in the area reported to include expansion of invasive plants (Prosopis juliflora), agricultural activity, drought, overgrazing, and firewood collection. The key informants also emphasized that Prosopis juliflora as a major threat to the ethno-veterinary plant species, which cover 
Citation: Mengistu M, Kebede E, Serda B (2017) Ethnobotanical Knowledge of Pastoral Community for Treating Livestock Diseases in Shinle Zone, Somali Regional State, Eastern Ethiopia. J Vet Sci Technol 8: 474. doi: 10.4172/2157-7579.1000474

Page 5 of 8

\begin{tabular}{|c|c|c|c|c|c|c|c|c|c|c|c|c|c|c|}
\hline \multirow{2}{*}{ Plant species to treat livestock diarrhea } & \multicolumn{14}{|c|}{ Key informants (1-12) } \\
\hline & 1 & 2 & 3 & 4 & 5 & 6 & 7 & 8 & 9 & 10 & 11 & 12 & Total & Rank \\
\hline Acalyph indica. $\mathrm{L}$ & 2 & 5 & 3 & 5 & 4 & 4 & 3 & 5 & 4 & 3 & 4 & 5 & 47 & 1 \\
\hline Mentha longifolia L & 1 & 2 & 4 & 3 & 3 & 2 & 5 & 2 & 2 & 4 & 5 & 3 & 36 & 3 \\
\hline Butea monosperma. Taub & 4 & 3 & 1 & 1 & 2 & 3 & 2 & 4 & 3 & 2 & 3 & 2 & 30 & 5 \\
\hline Balanites aegyptiaca & 3 & 1 & 2 & 4 & 1 & 1 & 4 & 1 & 5 & 1 & 2 & 1 & 33 & 4 \\
\hline Olea europeae. L & 5 & 4 & 5 & 2 & 5 & 5 & 1 & 3 & 1 & 5 & 1 & 4 & 46 & 2 \\
\hline
\end{tabular}

Table 4: Result of preference ranking of medicinal plants reported for treating livestock diarrhea. N.B: Score in the table indicate ranks to given to medicinal plants based on their efficiency. Highest number (5) for plant remedy that the key informants thought was most effective in treating livestock diarrhea in the study area and the lowest number (1) for the least effective plant remedy.

\begin{tabular}{|c|c|c|}
\hline Factors & Number of informant listed \\
\hline Expansion of Prosopis juliflora & 48 & 39 \\
\hline Agricultural activity & 37 & 26.7 \\
\hline Drought & 21.7 \\
\hline Overgrazing & 20.5 \\
\hline Collection as fire wood & 25 & 17.2 \\
\hline Total & 180 \\
\hline
\end{tabular}

Table 5: List of different factors that affect medicinal plant species in the study area.

\begin{tabular}{|c|c|c|c|c|c|c|c|c|c|}
\hline $\begin{array}{c}\text { Scientific } \\
\text { names of plant }\end{array}$ & Family & $\begin{array}{l}\text { Local name of } \\
\text { plants }\end{array}$ & $\begin{array}{l}\text { Growth } \\
\text { form }\end{array}$ & $\begin{array}{l}\text { Diseases } \\
\text { treated }\end{array}$ & Parts used & $\begin{array}{l}\text { Form } \\
\text { used }\end{array}$ & $\begin{array}{l}\text { Method of } \\
\text { preparation }\end{array}$ & $\begin{array}{l}\text { Dosage administered/ } \\
\text { Route of admini. }\end{array}$ & $\begin{array}{l}\text { Livestock } \\
\text { type }\end{array}$ \\
\hline $\begin{array}{c}\text { Berberis lyceum. } \\
\text { Royle }\end{array}$ & Berberidaceae & Shifowayne & Sh & $\begin{array}{l}\text { CCPPI } \\
\text { Cough }\end{array}$ & Root & $\mathrm{Dr}$ & $\begin{array}{l}\text { Chopped with } \\
\text { water }\end{array}$ & 1 litter, oral & $\begin{array}{c}\text { Camel, cattle, } \\
\text { goat and } \\
\text { sheep }\end{array}$ \\
\hline $\begin{array}{l}\text { Paederia foetida. } \\
L\end{array}$ & Rubiaceae & Carmo'sageer & Sh & Wound healing & Root & $\mathrm{Fr}$ & $\begin{array}{l}\text { Roots Chopped } \\
\text { with water }\end{array}$ & $\begin{array}{l}\text { Wash for the injured part } \\
\text { for 3-4 times, topical }\end{array}$ & $\begin{array}{c}\text { Camel, cattle, } \\
\text { goat and } \\
\text { sheep }\end{array}$ \\
\hline Trichilia spp. & Meliaceae & Malmal & $\mathrm{T}$ & $\begin{array}{l}\text { Ectoparasites } \\
\quad \text { (ticks) }\end{array}$ & Seed & $\mathrm{Dr}$ & $\begin{array}{l}\text { Chopped with } \\
\text { water and } \\
\text { extract }\end{array}$ & $\begin{array}{l}\text { Wash external parasite } \\
\text { few days, topical }\end{array}$ & $\begin{array}{c}\text { Camel, cattle, } \\
\text { goat and } \\
\text { sheep }\end{array}$ \\
\hline $\begin{array}{c}\text { Indigofera } \\
\text { amorphoides. } \\
\text { Jaub }\end{array}$ & Fabaceae & Duqus & $\mathrm{H}$ & Bloating & Seed & $\mathrm{Fr} / \mathrm{dr}$ & $\begin{array}{l}\text { Crushed with } \\
\text { water }\end{array}$ & $1 / 4$ liter, oral & Cattle \\
\hline Acalyph indica. $\mathrm{L}$ & Euphorbiaceae & Shunfax/salid & $\mathrm{H}$ & Diarrhea & Leaf & $\mathrm{Dr}$ & $\begin{array}{c}1 / 4 \mathrm{~kg} \text { of leaves } \\
\text { powders mixed } \\
\text { in water }\end{array}$ & given orally & Camel \\
\hline $\begin{array}{l}\text { Aspharagus } \\
\text { racemosus. Mill }\end{array}$ & Liliaceae & Dhiiga dumarka & $\mathrm{H}$ & Bloating & Rhizome & $\mathrm{Dr}$ & $\begin{array}{l}\text { Rhizome } \\
\text { powder mixed } \\
\text { with water }\end{array}$ & $\begin{array}{l}\text { 4-5 pieces of rhizome } \\
\text { 2cup, oral }\end{array}$ & Camel \\
\hline Olea europeae. L & Olearaceae & Dhaqabka & $\mathrm{T}$ & Diarrhea & Leaf & $\mathrm{Fr}$ & $\begin{array}{l}\text { Leaves were } \\
\text { Chopped and } \\
\text { mixed }\end{array}$ & 1cup given, oral & Goats \\
\hline $\begin{array}{l}\text { Euphorbia } \\
\text { abyssinica }\end{array}$ & Euphorbiaceae & Cir wisiisi & Sh & Evil eye & $\begin{array}{l}\text { Leaf and } \\
\text { root }\end{array}$ & $\mathrm{Fr}$ & $\begin{array}{l}\text { Crushed and } \\
\text { mixed with } \\
\text { water \& drink }\end{array}$ & $1 / 4$ liter, oral & Sheep/goat \\
\hline $\begin{array}{c}\text { Malva neglecta. } \\
\text { Wall }\end{array}$ & Euphorbiaceae & Qalan & Sh & Body swell & Root & $\mathrm{Fr}$ & $\begin{array}{l}\text { Chopped with } \\
\text { water }\end{array}$ & 1lit, oral & Camel \\
\hline $\begin{array}{c}\text { Aloe } \\
\text { trichosantha. } \\
\text { Berger }\end{array}$ & Aloeaceae & Daqalsa & $\mathrm{H}$ & $\begin{array}{l}\text { CCPPI } \\
\text { Cough }\end{array}$ & $\begin{array}{l}\text { Leaf, stem } \\
\text { and root }\end{array}$ & $\mathrm{Fr}$ & $\begin{array}{c}\text { Fresh parts } \\
\text { were chopped } \\
\text { and juice given }\end{array}$ & 2cups, oral & Cattle \\
\hline $\begin{array}{l}\text { Azadirachta } \\
\text { indica. Juss }\end{array}$ & Meliaceae & Geed hindi & $\mathrm{T}$ & Body swell & $\begin{array}{l}\text { Leaf, stem } \\
\text { and root }\end{array}$ & $\mathrm{Fr}$ & $\begin{array}{c}\text { Extracts mixed } \\
\text { with water and } \\
\text { salt }\end{array}$ & Depend on type, oral & $\begin{array}{l}\text { Cattle, camel } \\
\quad \& \text { goat }\end{array}$ \\
\hline $\begin{array}{l}\text { Syzygium } \\
\text { cumini. L }\end{array}$ & Myrtaceae & Wiyiil & $\mathrm{T}$ & Diarrhea & $\begin{array}{l}\text { Leaf, stem } \\
\quad \& \text { root }\end{array}$ & $\mathrm{Fr}$ & $\begin{array}{c}\text { Stem bark juice } \\
\text { given twice a } \\
\text { day }\end{array}$ & 1lit, decoction & Camel \\
\hline \multirow{2}{*}{$\begin{array}{c}\text { Pueraria } \\
\text { tuberose. Will }\end{array}$} & \multirow[b]{2}{*}{ Fabaceae } & \multirow[b]{2}{*}{ Lalayas } & \multirow[b]{2}{*}{ Sh } & \multirow[b]{2}{*}{ Kidney problems } & \multirow{2}{*}{$\begin{array}{l}\text { Leaf and } \\
\text { root }\end{array}$} & \multirow[b]{2}{*}{$\mathrm{Fr}$} & \multirow{2}{*}{$\begin{array}{l}\text { Crushed leaf } \\
\text { or root extract } \\
\text { given orally }\end{array}$} & Depend type of size & \multirow{2}{*}{$\begin{array}{l}\text { Camel and } \\
\text { cattle }\end{array}$} \\
\hline & & & & & & & & decoction & \\
\hline Rumex nervosus & Polygonaceae & Barartiire & $\mathrm{H}$ & Eye problems & Root & $\mathrm{Dr}$ & $\begin{array}{l}\text { Root powder } \\
\text { used to heal } \\
\text { wound }\end{array}$ & 2 spoons, topical & Goat \\
\hline $\begin{array}{c}\text { Mallotus } \\
\text { philipennsis. Lam }\end{array}$ & Euphorbiaceae & Dibbaw & $\mathrm{H}$ & Hayna bite & $\begin{array}{l}\text { Leaf, stem } \\
\text { and root }\end{array}$ & $\mathrm{Fr} / \mathrm{Dr}$ & $\begin{array}{l}\text { Liquid juice over } \\
\text { the wound }\end{array}$ & wash the wound & Camel \\
\hline
\end{tabular}


Citation: Mengistu M, Kebede E, Serda B (2017) Ethnobotanical Knowledge of Pastoral Community for Treating Livestock Diseases in Shinle Zone, Somali Regional State, Eastern Ethiopia. J Vet Sci Technol 8: 474. doi: 10.4172/2157-7579.1000474

Page 6 of 8

\begin{tabular}{|c|c|c|c|c|c|c|c|c|c|}
\hline $\begin{array}{l}\text { Nicotiana } \\
\text { tobacum }\end{array}$ & Solanaceae & Jiic & $\mathrm{H}$ & Body swell & Leaf & $\mathrm{Fr}$ & $\begin{array}{l}\text { Leaves crushed } \\
\text { with water }\end{array}$ & 2cups, nasal & $\begin{array}{l}\text { Cattle and } \\
\text { camel }\end{array}$ \\
\hline $\begin{array}{l}\text { Euphorbia } \\
\text { geniculate }\end{array}$ & Euphorbiaceae & in & $\mathrm{H}$ & Skin diseases & Root & $\mathrm{Fr}$ & $\begin{array}{l}\text { Roots grounded } \\
\text { and extract juice }\end{array}$ & 1 lit, polish over the skin & $\begin{array}{l}\text { Camel and } \\
\text { goat }\end{array}$ \\
\hline Aloe spp & Aloaceae & Dacar & Sh & Snake bite & Root & $\mathrm{Fr}$ & $\begin{array}{c}\text { Chop with water } \\
\text { and wash }\end{array}$ & One and half lit, topical & Young camel \\
\hline $\begin{array}{c}\text { Vernonia } \\
\text { amygdalina }\end{array}$ & Asteraceae & Calyocad & $\mathrm{T}$ & Internal parasite & $\begin{array}{l}\text { Leaf, stem } \\
\text { and root }\end{array}$ & $\mathrm{Fr}$ & $\begin{array}{l}\text { Chop with water } \\
\text { and given orally }\end{array}$ & 2cups, oral & $\begin{array}{c}\text { Camel, cattle } \\
\text { sheep }\end{array}$ \\
\hline $\begin{array}{l}\text { Lawsonia } \\
\text { inermis. L }\end{array}$ & Lythraceae & Calyodhig & $\mathrm{T}$ & Diarrhea & Root & $\mathrm{Fr}$ & $\begin{array}{l}\text { Grounded fresh } \\
\text { root mixed with } \\
\text { camel milk }\end{array}$ & 1cup, decoction & Cattle \\
\hline Acacia oerfota & Fabaceae & Xiiga & Sh & Kidney problem & $\begin{array}{l}\text { Leaf, stem } \\
\text { and root }\end{array}$ & $\mathrm{Fr}$ & $\begin{array}{l}\text { Parts were } \\
\text { grounded and } \\
\text { mixed with } \\
\text { water }\end{array}$ & $\begin{array}{c}1-2 \text { cups based on size } \\
\text { decoction }\end{array}$ & Cattle \\
\hline $\begin{array}{c}\text { Senna } \\
\text { alexandrina. Mill }\end{array}$ & Fabaceae & Jaleelo & Sh & Internal parasite & Leaf & $\mathrm{Dr}$ & $\begin{array}{l}\text { Mix powder with } \\
\text { water and drink }\end{array}$ & 2cups, oral & $\begin{array}{l}\text { Cattle, goat } \\
\text { and sheep }\end{array}$ \\
\hline $\begin{array}{c}\text { Solanium } \\
\text { hastifolium. } \\
\text { Hochst }\end{array}$ & Solanaceae & Kariir & Sh & Rabies & Root & $\mathrm{Fr}$ & $\begin{array}{c}\text { Crush root bark } \\
\text { with water }\end{array}$ & 2cup, decoction & Camel \\
\hline Senna italic. Mill & Fabaceae & Jaleloo & Sh & Rabies & Leaf & $\mathrm{Dr}$ & $\begin{array}{l}\text { Dried leaf } \\
\text { powder }\end{array}$ & $1 / 2$ lit, decoction & $\begin{array}{l}\text { Goat and } \\
\text { sheep }\end{array}$ \\
\hline $\begin{array}{c}\text { Mentha } \\
\text { longifolia. L }\end{array}$ & Lamiaceae & Xabakadi & Sh & Diarrhea & Root & $\mathrm{Fr}$ & $\begin{array}{l}\text { Roots were } \\
\text { boiled \& given } \\
\text { to cattle }\end{array}$ & 2 cups, oral & Camel \\
\hline $\begin{array}{c}\text { Butea } \\
\text { monosperma. } \\
\text { Taub }\end{array}$ & Fabaceae & Dhaqab & $\mathrm{T}$ & Diarrhea & Leaf & $\mathrm{Fr}$ & $\begin{array}{l}\text { Leaves were } \\
\text { crushed with } \\
\text { water }\end{array}$ & 1lit, oral & Cattle \\
\hline $\begin{array}{c}\text { Balanites } \\
\text { aegyptiaca }\end{array}$ & Balanitaceae & Geed dhqii & $\mathrm{T}$ & Diarrhea & Root & $\mathrm{Fr}$ & $\begin{array}{l}\text { Grounded root } \\
\text { juice }\end{array}$ & 1lit, decoction & Goat \\
\hline $\begin{array}{l}\text { Cyperus } \\
\text { rotundus. } \mathrm{L}\end{array}$ & Cyperaceaea & -- & $\mathrm{H}$ & Fever/shivers & Root & $\mathrm{Fr}$ & $\begin{array}{l}\text { Root crushed } \\
\text { and juice given } \\
\text { orally }\end{array}$ & 2 cups, oral & $\begin{array}{l}\text { Cattle and } \\
\text { goat }\end{array}$ \\
\hline $\begin{array}{c}\text { Ruta } \\
\text { chalepensis. L }\end{array}$ & Rutaceae & Taltan & $\mathrm{H}$ & Wounds on skin & Leaf & $\mathrm{Fr}$ & $\begin{array}{c}\text { Leaves } \\
\text { grounded with } \\
\text { water }\end{array}$ & Wash twice a day, topical & $\begin{array}{l}\text { Cattle and } \\
\text { goat }\end{array}$ \\
\hline $\begin{array}{l}\text { Zinger officinale. } \\
\text { Rose }\end{array}$ & Zingiberaceae & Singibill & $\mathrm{H}$ & $\begin{array}{l}\text { CCPP/ } \\
\text { Cough }\end{array}$ & Rhizome & $\mathrm{Fr} / \mathrm{dr}$ & $\begin{array}{l}\text { Rhizome } \\
\text { crushed }\end{array}$ & $\begin{array}{c}\text { 1cup/1/2lit, nasal/ } \\
\text { decoction }\end{array}$ & Sheep/goat \\
\hline $\begin{array}{c}\text { Calpurnia aurea. } \\
\text { Benth }\end{array}$ & Fabaceae & Dhekat & Sh & Internal parasite & Leaf & $\mathrm{Fr}$ & $\begin{array}{c}\text { Crushed leaves } \\
\text { mixed with } \\
\text { water }\end{array}$ & 1 cup, oral & Sheep \\
\hline
\end{tabular}

Table 6: List of medicinal plants identified as ethno-veterinary for treatment of livestock ailments.

many parts of the land reducing capacity to grow medicinal plants as well as forage plants. This finding disagree with the result of Yibrah [30] who noted that the medicinal plants largely found in the natural habitats faced a major threat to their survival of the mother plants due to the combined effect of factors like cultivation of marginal lands and herbal preparation in the other part of the country. Likewise, Lulekal reported that deforestation due to agricultural expansion is the greatest threat to woody plants in southeast part of Ethiopia [23].

\section{Medicinal plant marketing}

Majority of medicinal plants were not on sale in the local markets of the study area, but only a few were reported to be sold, for instance, Nicotinum tobacum and Zinger officinale were available in market for sale as medicinal plants in few occasion as well as spices or stimulant. However, anyone who needs them for curing livestock disease should immediately contact the traditional healers in the community and described the symptoms of disease then healers soon collect appropriate plant part. Those traditional healers request a little charge for remedies but the charges vary based on the sources and availability of medicinal plants and number of animals treated. Traditional healers gave remedies free of charges for relatives.

\section{Conclusions}

Thirty-one plant species belonging to eighteen families identified to cure livestock health problems that have uncomplicated symptoms such as wound healing, local swellings, bloating, ectoparasites, tapeworm, diarrhea, snakebites, and rabies. Majority of plant species fall under Fabaceae and Euphorbiaceae family that are largely shrubs and principally collected from wild environment. The most commonly used plant parts were roots in fresh immediately after collection. Remedy preparation was mainly through chop then soaked overnight in concoction of water and salt then squeezed to separate liquid extract for plants used in fresh. However, few healers practice crushing and forming powder then diluted by water when need arise for plants leave used in dry form. Oral, topical and nasal route were the common mode of administration with no standardized dosing and treatment duration. The principal threats to medicinal plants were include expansion of invasive plants (Prosopis juliflora), drought, overgrazing, agricultural activity and firewood collection. Endogenous knowledge on ethno-veterinary medicinal plants was accepted orally from healer's forefathers and transmitted similarly to their children. Identified medicinal plants were not on sale in the local markets though healers requested a little charge. Awareness should raise and ethno-veterinary knowledge should integrate in to livestock extension delivery systems for the need to exploit the possibility of discovering more medicinally 
Citation: Mengistu M, Kebede E, Serda B (2017) Ethnobotanical Knowledge of Pastoral Community for Treating Livestock Diseases in Shinle Zone, Somali Regional State, Eastern Ethiopia. J Vet Sci Technol 8: 474. doi: 10.4172/2157-7579.1000474

viable plants and conservation measures should undertake to ensure the continued availability of effective medicinal plants. Further studies needed under controlled conditions on the efficacy and veterinary properties of such plant products and livestock disease treatments.

\section{Acknowledgements}

The authors would like to acknowledge Haramaya University, Office of Research affairs, for financial support. Also the authors would like to express cordial gratitude for agricultural office and people of Shinile Zone, who cooperated on providing all the necessary information and materials for the completion of this work. Finally; special thanks also go to field guidance's of study districts, Abdi and Hussen who assisted data collection and field observation.

\section{Conflict of Interest}

Authors declare that there is no existing conflict of interest.

\section{References}

1. Abbasi AM, Shujaul MK, Mushtaq, A, Mir AK, Cassandra LQ, et al. (2013) Botanical ethnoveterinary therapies in three districts of the Lesser Himalayas of Pakistan. J Ethnobiol Ethnomed 9: 84

2. Raj KV (2001) An ethnobotanical study of plants used for the treatment of livestock diseases in Tikamgarh District of Bundelkhand, Central India. Asian Pac J Trop Biomed 4: S460-467.

3. Dilshad SMR, Rehman NU, Ahmad N, lqbal A (2010) Documentation of ethnoveterinary practices for mastitis in dairy animals in Pakistan. Pak Vet $J$ 30: 167-171.

4. Edwards S (2001) The ecology and conservation status of medicinal plants on Ethiopia. Institute of Biodiversity Conservation and Research, Addis Ababa, pp: 46-55.

5. Bekele E (2007) Study on Actual Situation of Medicinal Plants in Ethiopia. Prepared for Japan Association for International Collaboration of Agriculture and Forestry, Addis Ababa.

6. FAO (2002) Genetics and animal health - Spotlight. 1st edn. Rome, p: 32.

7. Yineger H, Kelbessa E, Bekele T, Lulekal E (2007) Ethnoveterinary medicinal plants at Bale Mountains National Park, Ethiopia. J Ethnopharmacol 112: 55-70.

8. SC-UK, DPPB, Partners (2002) Shinile Pastoral Livelihood Zone. An HEA Baseline Study.

9. SC-UK, DPPA (2008) Livelihoods and Vulnerabilities: An Understanding of Livelihoods in Somali Regional State, Ethiopia.

10. Martin GJ (1995) Ethnobotany: A method Manual. London: Chapman and Hall, pp: $265-270$

11. Heinrich M, Ankli A, Frei B, Weimann C, Sticher O (1998) Medicinal plants in Mexico: Healers' consensus and cultural importance. Soc Sci Med 47: 18591871.

12. Luiz R, Saldanha G, Reinaldo F, Paiva de L, Ulysses P (2005) Knowledge and use of medicinal plants by local specialists in a region of Atlantic Forest in the state of Pernambuco (Northeastern Brazil). J Ethnobiol Ethnomed 1: 9.

13. Giday M, Asfaw Z, Woldu Z (2009) Medicinal plants of the Meinit ethnic group of Ethiopia: An ethnobotanical study. J Ethnopharmacol 124: 513-521.

14. Farooq Z, Iqbal Z, Mushtaq S, Muhammad G, Zafar M, et al. (2008) Ethnoveterinary practices for the treatment of parasitic diseases in livestock in Cholistan desert (Pakistan). J Ethnopharmacol 118: 213-219.

15. Yirga G, Zerabruk S (2011) Traditional knowledge of medicinal plants in Gindeberet district, Western Ethiopia. S Afr J Botany 103: 295-301.

16. Ashagre E, Ensermu K, Gemedo D (2016) Ethnobotanical study of medicinal plants in Guji Agro-pastoralists, Blue Hora District of Borana Zone, Oromia Region, Ethiopia. J Med Plants Stud 4: 170-184.

17. Gabriel A (2015) The Role of Medicinal Plants in Treatment of Cattle Diseases in Serere District. Uganda, MSc Thesis.

18. Nalule AS, Karue CN, Katunguka-Rwakishaya E (2011) Anthelmintic activity of Phytolacca dodecandra and Vernonia amygdalina leaf extracts in naturally infected small East African goats. Livest Res Rural Dev 23: 12.

19. Adeola OA, Adewole SO, Olofintoye LK (2014) Studies on Ethnoveterinary
Practice in Ruminants in Ekiti State, Nigeria. Res J Agricult Environ Manag 3: $632-645$.

20. Abebe D, Debella A, Urge K (2003) Medicinal plants and other useful plants of Ethiopia. EHNRI, Camerapix Publishers International, Nairobi, Kenya, pp: $25-43$.

21. Dire Dawa Administrative Council (DDAC) (2002) Dire Dawa administrative council integrated resources development master plan. Addis Ababa, Ethiopia 4: 44

22. Hunde D, Asfaw Z, Kelbessa $E$ (2006) Use of traditional medicinal plants by people of 'Boosat' sub district, Central Eastern Ethiopia. Ethiop J Health Sci 16: 141-155.

23. Lulekal E, Zemede A, Ensermu K, Patrick VD (2008) Ethnoveterinary plants of Ankober District, North Shewa Zone, Amhara Region, Ethiopia. J Ethnobiol Ethnomed 10: 21.

24. Bekalo HT, Demissew S, Asfaw Z (2009) An ethnobotanical study of medicinal plants used by local people in the lowlands of Konta Special Wereda, Southern Nations, Nationalities and Peoples Regional State, Ethiopia. J Ethnobio Ethnomed 5: 26

25. Mesfin F, Demissew S, Tekelaymanot T (2009) An Ethnobotanical study of medicinal plants in Wonago Woreda, SNNPR, Ethiopia. J Ethnobiol Ethnomed 5. 28

26. Giday M, Asfaw Z, Elmqvist T, Woldu Z (2003) An ethnobotanical study of medicinal plants used by the Zay people in Ethiopia. $J$ Ethnopharmacol 85: 43-52.

27. Tabuti JRS, Lye KA, Dhillion SS (2003) Traditional herbal drugs of Bulamogi Uganda: Plants, use and administration. J Ethnopharmacol 88: 19-44.

28. Giday M, Asfaw Z, Woldu Z (2010) Ethnomedicinal study of plants used by Sheko ethnic group of Ethiopia. J Ethnopharmacol 132: 75-85.

29. Muthu C, Ayyanar M, Raja N, Ignacimuthu S (2006) Medicinal plants used by traditional healers in Kancheepuram District of Tamil Nadu, India. J Ethnobio Ethnomed 2: 43

30. Yibrah T (2015) Medicinal Plants in the Ethno Veterinary Practices of Bensa Woreda, Southern Ethiopia. Open Access Library J 2: 1-12.

31. Balemie K, Kelbessa E, Asfaw Z (2004) Indigenous medicinal plant utilization, management and threats in Fentalle area, Eastern Shewa, Ethiopia. Ethiop J Biol Sci 3: 37-58.

32. Yineger $H$, Yewhalaw D, Teketay D (2008) Plants of veterinary importance in Southwestern Ethiopia: the case of Gilgel Ghibe area. Forests, Trees Livelihoods 18: 165-181.

33. Zenebe G, Zerihun M, Solomon Z (2012) An ethnobotanical study of medicinal plants in Asgede Tsimbila District, Northwestern Tigray, Northern Ethiopia. Ethnobotany Res Appl 10: 305-320.

34. Sinha P, Govil NJ, Singh VK (2002) Diseases and their management, recent progress in medicinal plants. Sci Tech, Pub LLC, USA, pp: 1-105.

35. Yirga G, Teferi M, Gidey G, Zerabruk S (2012) An ethnoveterinary survey of medicinal plants used to treat livestock diseases in Seharti-Samre district, Northern Ethiopia. Afr J Plant Sci 6: 113-119.

36. Habibul HH, Murad W, Tariq A, Ahmad A (2014) Ethnoveterinary study of medicinal plants in Malakand Valley, District Dir (Lower), Khyber Pakhtunkhwa, Pakistan. Ir Vet J 67: 6

37. Giday M, Ameni G (2003) An Ethnobotanical Survey on plants of veterinary importance in two weredas of Southern Tigray, Northern Ethiopia. Ethiop J Sci 26: $123-136$

38. Senai WA (2010) Legislative regulation of traditional medicinal knowledge in Eritrea vis-à-vis Eritrea's commitments under the Convention on Biological Diversity. Law Environ Dev J 6: 130-162.

39. Birhane E, Aynekulu E, Mekuria W, Endale D (2011) Management, use and ecology of medicinal plants in the degraded dry lands of Tigray, Northern Ethiopia. J Med Plants Res 5: 309-318.

40. Ragunathan M, Abay SM (2009) Ethnomedicinal survey of folk drugs used in Bahirdar Zuria District, Northwestern Ethiopia. Indian J Tradit Knowledge 8: 281-284.

41. Deeba $F$ (2009) Documentation of ethnoveterinary practices in urban and 
Citation: Mengistu M, Kebede E, Serda B (2017) Ethnobotanical Knowledge of Pastoral Community for Treating Livestock Diseases in Shinle Zone, Somali Regional State, Eastern Ethiopia. J Vet Sci Technol 8: 474. doi: 10.4172/2157-7579.1000474

peri-urban areas of Faisalabad, Pakistan. Faisalabad, Pakistan. PhD Thesis, University of Agriculture.

42. Hunde D, Asfaw Z, Kelbessa E (2004) Use and management of Ethnoveterinary medicinal plants by indigenous people in 'Boosat', Welenchiti area. Ethiop $\mathrm{J}$ Biol Sci 3: 113-132.

43. Abebe D, Ayehu A (1993) Medicinal Plants and Enigmatic Health Practices of Northern Ethiopia. Ethiopia. Berhanena Selam Printing Enterprise: Addis Ababa.

44. Teshale S, Merga B, Girma A, Ensermu K (2004) Medicinal plants in the ethnoveterinary practice of Borena Pastoralists, Southern Ethiopia. Int J Appl Res Vet Med 2: 220-225.

45. Kebu B, Ensermu K, Zemede A (2004) Indigenous medicinal utilization, management and threats in Fentale area, Eastern Shewa, Ethiopia. Ethiop J Biol Sci 3: 37-58.
46. Getahun A (1976) Some common medicinal and poisonous plants used in Ethiopian folk medicine.

47. Barboza RRD, Souto WMS, Mourão JS (2007) The use of zootherapeutics in folk veterinary medicine in the district of Cubati, Paraiba State, Brazil. J Ethnobiol Ethnomed 3: 1-14

48. Monteiro MV, Bevilaqua CML, Palha MDC, Braga RR, Schwanke K, et al (2011) Ethnoveterinary Knowledge of the Inhabitants of Marajó Island, Eastern Amazonia, Brazil. Acta Amaz 41: 233-242.

49. Cunningham AB, Zondi AS (1991) Cattle owners and traditional medicines used for livestock. Investigational Report at Institute of Natural Resources, University of Natal, Pietermaritzburg, No. 69.

50. Masika PJ, Van Averbeke W, Sonandi A (2000) Use of herbal remedies by small-scale farmers to treat livestock diseases in central Eastern Cape Province, South Africa. J S Afr Vet Assoc 71: 87-91. 